\title{
A colaboração premiada como instrumento de política criminal: a tensão em relação às garantias fundamentais do réu colaborador
}

The plea bargain as a criminal policy instrument: the tension about the fundamental guarantees of the defendant

\section{Murilo Thomas Aires ${ }^{1}$}

Bacharel em Direito pela Universidade Estadual

Paulista Júlio de Mesquita Filho

t.aires94@gmail.com

http://lattes.cnpq.br/4693423630226107

D http://orcid.org/0000-0003-2981-4238

Fernando Andrade Fernandes ${ }^{2}$

Doutor em Direito pela Universidade de Coimbra Professor da Universidade Estadual Paulista Júlio de Mesquita Filho feranfer@uol.com.br

http://lattes.cnpq.br/0485191470301548

http://orcid.org/0000-0002-6801-3356

Resumo: O presente estudo almeja analisar a colaboração premiada a partir de sua fundamentação político-criminal, de modo a atingir a tensão que mantém em relação a determinadas garantias fundamentais do acusado, sobretudo daquele que firma o acordo. Nesta ocasião, será realizada, substancialmente, uma contraposição entre o procedimento legal de colaboração e os princípios do contraditório,

1 Bacharel em Direito pela Faculdade de Ciências Humanas e Sociais - Unesp Campus Franca (2017).

2 Possui graduação em Direito pela Universidade Estadual Paulista Júlio de Mesquita Filho (1987), mestrado em Direito pela Universidade Federal de Minas Gerais (1992), doutorado em Direito pela Universidade de Coimbra (2000) e pós-doutorado em Direito Penal pela Universidade de Salamanca (2011). Atualmente é professor Assistente doutor da Universidade Estadual Paulista Júlio de Mesquita Filho. 
da ampla defesa, da presunção de inocência, e da não-autoincriminação. A aplicação da colaboração premiada se mostra extremamente controvertida não só no senso comum, frequentemente veiculado pelos meios de comunicação, mas principalmente na perspectiva técnica, especialmente em relação ao debate científico, o que reflete a complexidade do tema proposto. Para uma efetiva abordagem do tema, o trabalho faz-se valer dos métodos dedutivo, histórico-evolutivo e dialético, sendo a pesquisa bibliográfica a técnica fundamentalmente utilizada.

Palavras-chave: Colaboração premiada; Política criminal; Justiça Criminal Consensual; Garantias fundamentais; Réu-colaborador.

ABSTRACT: The present research intends to analyze the plea bargaining based on its political-criminal foundation, in order to achieve the tension it maintains in relation to certain fundamental guarantees of the defendant, especially the one who signs the agreement. On this occasion, there will be substantially a contraposition between the legal procedure of collaboration and the principles of the adversary, ample defense, presumption of innocence, and non-self-incrimination. The application of the plea bargain proves extremely controversial not only in the common sense, often conveyed by the media, but mainly in the technical perspective, especially in relation to the scientific debate, which reflects the complexity of the proposed theme. For an effective approach to the theme, the work uses the deductive, historical-evolutionary and dialectical methods, being the bibliographical research the technique fundamentally used.

KEYwords: Plea bargaining; Criminal Policy; Consensual criminal justice; Fundamental Guarantees; Defendant's plea.

SUMÁRIO: Introdução. 1. O processo penal como instrumento de política criminal. 2. O processo penal como instrumento de política criminal na criminalidade grave. 3 . Considerações gerais sobre a colaboração premiada: a justiça criminal consensual e os aspectos da voluntariedade e da segurança jurídica. 4. Dos princípios do contraditório e da ampla defesa no acordo de colaboração. 5 . Da presunção de inocência e da não autoincriminação no acordo de colaboração. Considerações finais. Referências bibliográficas. 


\section{INTRODUÇÃo}

A colaboração premiada é alvo de críticas que abrangem tanto as várias questões em aberto acerca de seu modus operandi, recentemente estabelecido pela Lei n. 12.850/13 (Lei das Organizações Criminosas), quanto ao seu enquadramento no Ordenamento Jurídico brasileiro, seja em relação à sua compatibilidade com a Constituição Federal de 1988, seja naquilo que se refere especificamente ao sistema processual penal.

Toma-se aqui a posição de que a colaboração premiada se apresenta como um instrumento de política criminal, surgindo como um influxo relativo à necessidade de maior eficiência no cumprimento das funções do Sistema Jurídico-Criminal. No entanto, este influxo deve respeitar a irrenunciável tradição garantista do processo penal contemporâneo, sobretudo tratando-se de um modelo de Estado Democrático de Direito. Mais que isso, tendo em vista este paradigma, tal instrumento deve obedecer ao valor fundamental da tutela da dignidade da pessoa humana.

Todavia, a realidade complexa de um acordo de colaboração premiada requer uma densa elaboração legislativa, sob pena de permitir-se várias ofensas às garantias do réu, seja colaborador ou delatado, de maneira e ferir-se drasticamente a tutela da dignidade humana, valor este que deve representar uma barreira intransponível.

É com vistas a isso que aqui se propõe, a partir da fundamentação político criminal da colaboração premiada, analisar o procedimento recém estabelecido pela Lei $n^{0} 12.850 / 13$, enquanto expressão da justiça consensual no âmbito processual penal, em confronto com as garantias fundamentais na perspectiva do réu colaborador, representadas aqui, por conveniência, pelo contraditório, ampla defesa, presunção de inocência, e pela não autoincriminação.

Levando em consideração a complexidade do tema proposto, este estudo não se satisfaz com somente um método de abordagem, utilizando-se, além do método dedutivo - partindo-se da tese mais ampla do processo penal como instrumento de política criminal, até se alcançar o particular da colaboração premiada - o método histórico -evolutivo, de forma a analisar, mesmo que de modo breve, os antecedentes do objeto de estudo, além do método dialético, em face da 
contraposição entre o procedimento legal e as garantias fundamentais do réu colaborador. A pesquisa bibliográfica foi a técnica primordial no desenvolvimento do trabalho.

\section{O PROCESSO PENAL COMO INSTRUMENTO DE POLÍTICA CRIMINAL}

A busca por uma melhor integração entre os elementos de um Sistema Jurídico-Penal, que permita uma dinâmica funcional deste sistema, de modo a integrar nesta dinâmica o pensamento problemático e o pensamento sistemático ${ }^{3}$, reflete-se na necessidade de um novo posicionamento da política-criminal em relação ao Direito Penal, de modo que haja a presença de decisões valorativas de política criminal na própria estruturação básica do Direito Penal, em sua própria elaboração normativa ${ }^{4}$.

Este raciocínio deve se estender ao Direito Processual Penal, de modo que se mostra cabível a influência de valorações de política criminal na própria elaboração normativa processual. Nesse sentido, a argumentação realizada por Jorge de Figueiredo Dias sobre ser um processo penal funcionalmente orientado uma verdadeira exigência irrenunciável do Estado de Direito, visto que tem este o dever de realizar a justiça de modo rápido e eficiente, de forma que transmita à sociedade confiança na funcionalidade das instituições públicas ${ }^{5}$.

Além da expansão do pensamento funcionalista ao Direito Processual Penal, confere-se atualmente uma real utilização do processo

3 Atestando a necessidade de um maior diálogo entre as ciências jurídico-penais, para que se avance em um efetivo contato com a realidade e a praticabilidade do Sistema Jurídico-Criminal: RODRIGUES, Anabela Maria M. A determinação da medida da pena privativa de liberdade. Coimbra: Coimbra Editora, 1995.

4 O desenvolvimento deste raciocínio se encontra amplamente elaborado nas obras: ROXIN, Claus. Política criminal e sistema jurídico penal. Tradução: Luis Greco. Rio de Janeiro: Renovar, 2000; ROXIN, Claus. Estudos de Direito Penal. Tradução: Luís Greco. Rio de Janeiro. Renovar, 2006; também sendo primordial no assunto o que se expõe na obra DIAS, Jorge Figueiredo. Os novos rumos da política criminal e o direito penal português do futuro. Coimbra: ROA, 1983.

5 DIAS, Jorge de Figueiredo. Acordos sobre a sentença em processo penal: o fim do Estado de Direito ou um novo "princípio"? Porto: Conselho Distrital do Porto da Ordem dos Advogados, 2011. p. 37. 
penal como instrumento de política $\mathrm{criminal}^{6}$, dinâmica nova esta que vem se identificando como uma marca no desenvolvimento contemporâneo do Sistema Jurídico-Penal.

Através do processo penal como instrumento de política criminal, propõe-se "a inserção do processo penal no âmbito geral da política criminal, de modo que na sua estruturação se levem em conta também as intenções político-criminais que orientem o Sistema Jurídico-Penal como um todo" ", sugerindo-se uma reconstrução do processo penal em termos de política criminal, para alcançar-se uma maior funcionalidade e eficiência processual, sem, contudo, abandonar a fundamental e irrevogável natureza garantística. Desse modo, indica-se a imposição de "uma ponderação entre os interesses da funcionalidade e garantia, tendo como limite a indispensabilidade ao máximo daquelas garantias que se fizerem necessárias para a tutela da dignidade humana". ${ }^{8}$ Esta tensão entre o eficientismo e o garantismo reflete, sem sombra de dúvidas, uma das principais polêmicas acerca da proposta em questão.

Com efeito, é inegável a relevância dos fatores funcionalidade/eficiência no Sistema Jurídico-Penal, especialmente no que se refere ao procedimento penal. Afinal, um processo penal que pouco se presta tanto às suas próprias funções, como às diretrizes do Direito Penal material, não pode ser outra coisa que não pernicioso. Exemplar deste fato é a questão da celeridade processual.

Um processo penal moroso traz vários problemas de natureza político criminal. Primeiramente, a lenta tramitação abre um caminho somente de entrada de demandas penais, as quais demoram a encontrar um caminho de saída. Dessa forma, a proporção entre os processos que se criam, e os que se finalizam, gera, por óbvio, um exacerbado contingente o qual torna impossível, por exemplo, o devido respeito aos prazos previstos na lei.

Ademais, a lentidão processual causa um dano crucial na produção probatória do caso concreto, afinal os vestígios do fato geralmente se desfazem no lapso temporal. Outro aspecto crítico - o qual se mos-

6 FERNANDES, Fernando Andrade. O processo penal como instrumento de política criminal. Coimbra: Almedina, 2001. p. 53-ss.

7 Ibid. p. 53.

8 Ibid. p. 67. 
tra como um dos grandes problemas de todo o Ordenamento Jurídico brasileiro - é aquele relativo à segurança jurídica. Por vezes se tem o alimento à sensação de impunidade por parte da opinião pública, e a "quebra de confiança dos cidadãos numa tutela jurídica eficaz", o que pode nutrir até mesmo uma tendência à autodefesa.

E não é diferente por parte do acusado já que este também sofre com a insegurança jurídica, tendo em vista que se permanece em incerteza sobre o veredito final do processo, estando ele ainda, eventualmente, detido preventivamente até o provimento jurisdicional.

Aqui não se pretende negar, principalmente no que toca ao grande contingente de demandas, a inflação dos tipos penais previstos no Sistema Jurídico-Penal brasileiro como também prejudicial à funcionalidade e à eficiência do mesmo, essencialmente no que tange às lesões de menor potencial ofensivo, e às contravenções penais. Contudo, não há como se contrariar a constatação de que o problema da celeridade também se mostra interno ao Direito Penal de natureza processual. A questão da celeridade como meio para o fim eficiência/funcionalidade é um dos tópicos substanciais na exploração do processo penal como instrumento de política criminal através da Lei n. 9.099/95, que institui os Juizados Especiais Criminais no Ordenamento Jurídico brasileiro.

Outrossim, novos e complexos tipos penais vêm sendo criados, bem como se desenvolvem as formas de execução de tipos já prescritos na lei há algum tempo, o que pode dificultar a comprovação desses delitos em face da insuficiência dos meios tradicionais de prova. Neste contexto, verse-á que pelos influxos de política criminal - com a preocupação políticocriminal sobre a funcionalidade e a eficiência do processo penal nesses casos - na própria elaboração legislativa do processo penal, surge de fato a previsão legal de um procedimento de colaboração premiada no Brasil.

Por outro lado, não necessariamente contrário ao vetor funcionalidade/eficiência, mas naturalmente conflitante a este, tem-se o vetor garantia $^{10}$, o qual representa fundamental significado ao processo penal.

9 Ibid. p. 55.

10 Sobre a doutrina do garantismo penal, imprescindível consultar da obra: FERRAJOLI, Luigi. Direito e razão: teoria do garantismo penal. 3 ed. rev. São Paulo: Editora Revista dos Tribunais, 2010. 
Afinal, as garantias fundadas no âmbito do Direito Penal e processual representam verdadeira justificação à sua utilização. ${ }^{11}$ Ademais, os princípios garantísticos são essenciais à possibilidade de estruturação de um Direito Penal coerente com um Estado Democrático de Direito, modelo de Estado eleito pela Constituição Federal brasileira de $1988^{12}$.

Ainda, pode se considerar as garantias do Direito Penal como sua verdadeira legitimação, "tendo em vista que os visados, neles incluídos o acusado real e o potencial, somente reconhecerão a validade de uma intervenção de natureza penal que se faça sob as garantias necessárias"13.

Exposta brevemente a relevância dos vetores funcionalidade e eficiência, e a indispensabilidade do vetor garantia, propõe-se que, utilizando-se do processo penal como instrumento de política criminal, introduza-se "no seio do próprio processo legal - sem prejuízo para os postulados essenciais - mecanismos tendentes à obtenção de sua maior eficácia, depurando-o daquelas garantias cuja previsão seja desnecessária" ${ }^{14}$. Ou seja, preconiza-se que em nome de uma maior eficiência no processo legal, dispensem-se garantias que se mostrem prescindíveis, de forma que, no entanto, não se prejudiquem os postulados essenciais. Mas o que seriam estes postulados essenciais?

Em razão da importância dos princípios garantísticos, a valoração de uma complementariedade funcional entre o Direito Penal material e o processual deve ter como limite o vetor garantia no processo penal. Afinal, observa-se que o valor preponderante no modelo de Estado Democrático de Direito se encontra na preocupação com a tutela da dignidade humana.

11 HASSEMER, Winfried. La ciência jurídico penal em la república federal alemana. Trad. Hernán Hormanazabal Malarée. Anuario de Derecho Penal y Ciencias Penales. t. XLVI, f. I. Madrid: ene./abr. 1993. p. 35-80. p. 79.

12 Sobre a coerência entre o modelo de Estado e o modelo de Direito Penal, cabe consultar-se a obra FERNANDES, Fernando Andrade. Sobre uma opção jurídico-política e jurídico-metodológica de compreensão das ciências jurídicocriminais. In: COSTA ANDRADE, Manuel da et al. (Org.). Liber Discipulorum para Jorge de Figueiredo Dias. Coimbra: Editora Coimbra, 2003.

13 FERNANDES, Fernando Andrade. O processo penal como instrumento de política criminal. Coimbra: Almedina, 2001. p. 57.

14 Ibid. p. 65. 
Em consequência, adotando-se esse regime constitucional, não há como se falar em qualquer renúncia às normas correlatas a esse princípio por parte do respectivo processo penal. Assim, neste contexto, o limite da sobredita complementariedade funcional deve ser a indisponibilidade da proteção da dignidade humana, representando os questionados postulados essenciais, no Estado Democrático de Direito, a base principiológica e garantística que mantenha intocada a dignidade humana.

Além dessa conciliação ao mesmo tempo das necessidades de garantia do cidadão, com os não menos necessários fatores de funcionalidade e eficiência do Sistema Jurídico-Penal, o desenvolvimento da tese sustenta que para a possibilidade de conformação do processo penal com conjecturas de natureza político criminal no contexto social da sua aplicação, deve se possibilitar a consideração de prognósticos de natureza político criminal na própria estrutura do processo penal.

Em síntese, isto significa que deve haver na própria estrutura do processo penal a reserva de espaços para a consideração criteriosa de prognósticos de valores político criminais na atuação concreta do processo penal, de modo que se permita uma diversificação de procedimentos, em conformidade com o sentido destes prognósticos. Por outras palavras, o processo penal não deve admitir um automatismo da aplicação das penas e levar em conta somente critérios limitados aos elementos constitutivos da infração; mas sim, estabelecer critérios voltados para a obtenção da finalidade político criminal. ${ }^{15}$

Por fim, tem-se ainda a necessidade de uma integração teleológica do processo penal, de forma a realizar a harmonia entre as finalidades político criminais do Sistema Jurídico-Penal como um todo, e o modelo processual nele adotado. Essa integração se trata da própria concretização da conciliação entre os vetores funcionalidade/eficiência e garantia, e da estruturação de um conteúdo prognóstico do processo penal ${ }^{16}$.

Sendo assim, para um processo penal não apenas limitado à proteção do acusado, mas também em conformidade com os valores políticos criminais do Sistema Jurídico-Penal como um todo, deve se

15 FERNANDES, Fernando Andrade. O processo penal como instrumento de política criminal. Coimbra: Almedina, 2001. p. 70.

16 Ibid. p. 73. 
realizar uma integração teleológica entre o Sistema Punitivo, e o modelo processual nele adotado, havendo uma estrutura da norma processual que permita em si um conteúdo prognóstico, de maneira que também se cumpram as necessidades de funcionalidade e eficiência do processo penal, sem dispensar sua irrenunciável tradição de garantia, irrenunciabilidade que se representa, no Estado Democrático de Direito, pela intransponível tutela da dignidade da pessoa humana.

\section{O PROCESSO PENAL COMO INSTRUMENTO DE POLÍTICA CRIMINAL NA CRIMINALIDADE GRAVE}

Se na Lei n. 9.099/95, com a previsão de institutos como a transação penal e a suspensão condicional do processo, representou-se a utilização do processo penal como instrumento de política criminal com o estabelecimento de diversificações processuais no âmbito da criminalidade leve, outros mecanismos surgiram posteriormente a tratar, no mesmo sentido, da criminalidade grave ${ }^{17}$.

$\mathrm{O}$ artigo $3^{\circ}$ da Lei 12.850/13 traz todo um rol de mecanismos a serem aplicados na investigação de fatos relacionados a organizações criminosas, quais sejam: (a) a colaboração premiada; (b) a captação de sinais eletromagnéticos, ópticos ou acústicos; (c) a ação controlada; (d) o acesso a registros de ligações telefônicas e telemáticas, a dados cadastrais de bancos de dados públicos ou privados e a informações eleitorais ou comerciais; (d) a própria interceptação de comunicações telefônicas e telemáticas; (e) o afastamento do sigilo financeiro, bancário e fiscal; (f) a infiltração de policiais na atividade investigada; (g) a cooperação entre instituições e órgãos federais, distritais, estaduais,

17 Tendo em vista que a Lei $\mathrm{n}^{\circ}$ 9.099/95 estipulou aquilo que denominou de "crimes de menor potencial ofensivo" através da quantidade da pena em abstrato atribuída pelos tipos penais (pena máxima de 2 anos), categoria que representamos aqui por "criminalidade leve", de forma lógica refere-se aqui à criminalidade grave como a categoria de crimes em que se comina uma elevada quantidade de pena, como, no caso, os crimes de organização criminosa, que se caracterizam somente através de infrações penais cujas penas máximas sejam superiores a 4 (quatro) anos, a não ser aquelas de caráter transnacional (artigo $1^{\circ}, \S 1^{\circ}$, Lei $n^{\circ} 12.850 / 13$ ). 
e municipais na busca de provas e informações de interesse da investigação, ou da instrução criminal.

Evidentemente, alguns dos meios de prova estabelecidos são mais complexos e problemáticos que outros, atuando em aspectos distintos da criminalidade organizada, e de formas diversas. Eximindo-se aqui de se adentrar às questões profundas de cada um destes mecanismos, mormente no que se refere à sua legitimidade (o que neste trabalho se realizará somente em relação à colaboração premiada), é tranquilo afirmar-se que o rol estabelecido pelo artigo $3^{\circ}$ da Lei n. 12.850/13 reflete claramente uma gama de mecanismos processuais, os quais dispensam certas garantias dos acusados, em busca de uma maior eficiência da persecução criminal e, por consequência, do cumprimento de certas finalidades do Sistema Jurídico-Criminal, através de prognósticos estabelecidos pelo conceito de Organização Criminosa, e por outras legislações específicas, como no caso da interceptação telefônica.

Destarte, tal diversidade processual representa claramente o processo penal como instrumento de política criminal, orientado, nesta ocasião, por valorações político-criminais voltadas à criminalidade grave, em específico à criminalidade organizada. Contudo, agora não mais a preocupação referente à eficiência do processo penal se dá puramente com problemas relativos à morosidade do processo.

As transformações da sociedade contemporânea ${ }^{18}$ trouxeram novas descrições típicas, e novas formas de cometimento dos delitos, as quais se furtavam aos meios tradicionais de prova, de modo que se faria até mesmo impossível alguma edificação de determinados fatos pretéritos investigados, sob pena de drástico distanciamento do processo penal ao alcance da verdade ${ }^{19}$, o que além de refletir uma intensa insegurança

18 Sobre a configuração atual da sociedade, indispensável a leitura das obras BAUMAN, Zigmunt. Globalização: as consequências humanas. Tradução: Marcos Penchel. Rio de Janeiro: Editora Jorge Zahar, 1999; BECK, Ulrich. Sociedade de risco. Tradução: Sebastião Nascimento. 2. ed. São Paulo: Editora 34, 2011; e FARIA, José Eduardo. Direito e globalização econômica: implicações e perspectivas. São Paulo: Malheiros, 1996.

19 É importante destacar as críticas realizadas àquilo que se chama de verdade real, em vista de que não só a verdade dita "material" se mostra como um mito, ou até mesmo uma ingenuidade; como se mostra equivocada uma dicotomia entre a verdade material e a processual. Sobre essa discussão, imperiosa a con- 
jurídica, obsta o cumprimento de determinadas finalidades político-criminais do Sistema Jurídico-Criminal como um todo.

Os mecanismos estabelecidos pela Lei n. 12.850/13, entre eles a colaboração premiada, refletem claramente o processo penal em complementariedade funcional com o direito penal material, agora direcionado à criminalidade grave. Constata-se ainda que se antes se preocupava com a eficiência do processo penal dado o seu congestionamento, e a carência de celeridade do andamento processual; agora preocupa-se também com a dificuldade da própria investigação e, sendo assim, da própria possibilidade de edificação de fatos pretéritos que possam representar condutas delituosas taxadas como de maior gravidade.

Maior discussão se faz, entretanto, em relação à compatibilidade dos mecanismos estabelecidos pela Lei n. 12.850/13 com o Ordenamento Jurídico brasileiro, e se as garantias eventualmente afastadas realmente são desnecessárias à tutela da dignidade da pessoa humana, para que se mantenha coerência com o modelo processual penal eleito pela Constituição Federal brasileira de 1988.

\section{Considerações Gerais SObre A COlaboraÇão PREMIAdA ${ }^{20}:$ A JUSTIÇA CRIMINAL CONSENSUAL, E OS ASPECTOS DA VOLUNTARIEDADE E DA SEGURANÇA JURÍDICA}

A colaboração premiada é originalmente enquadrada no âmbito do Direito Penal Premial, sendo este uma perspectiva do estudo do Direito Penal focada, como o próprio nome infere, nas normas premiais,

sulta à fonte: MANDARINO, Renan Posella. Limites probatórios da delação premiada frente à verdade no processo penal. In: Aspectos penais controversos da colaboração premiada: monografias vencedoras 2016 - IASP|CIEE - Esther Figueiredo Ferraz. 1 ed. São Paulo: Editora IASP, 2016. p. 139-149.

20 Cumpre destacar, neste ponto, que, em que pese a Lei tenha trazido não só um novo procedimento, como também uma nova denominação para o instituto, definindo-o como "colaboração premiada" ao invés de "delação premiada”, entende-se aqui que colaboração premiada e delação premiada são termos sinônimos. Em alguns momentos, utiliza-se das diferentes nomenclaturas para diferenciar o novo modelo trazido pela Lei 12.850/13 (colaboração premiada), dos modelos antecedentes (delação premiada), entretanto a diferenciação tem caráter meramente ilustrativo, e não conceitual. 
ou seja, naquelas normas ligadas à ideia de concessão de um benefício previsto na lei para àquele que cometeu o delito, mas realizada determinada contra-conduta valorizada pela lei, seja na abrangência do arrependimento substantivo (em que há a exigência de reintegração da própria ofensa típica, anulando a ofensividade ao bem jurídico), seja no que tange ao arrependimento processual (em que o arrependido se coloca à disposição para colaborar com a repressão penal). ${ }^{21}$ Com efeito, a colaboração premiada se enquadra no que se denominou arrependimento processual.

A palavra prêmio gera certa controvérsia no estudo do Instituto, mostrando-se por vezes contraditória. Afinal, não expressa, em um primeiro momento, necessariamente um benefício positivo, mas sim a imposição de um mal menor ao indivíduo que cometeu o crime e depois colaborou para sua investigação. ${ }^{22}$ Sendo assim, a palavra prêmio deve ser entendida mais como um incentivo, ocorrendo este tanto em aspecto geral, quanto especial.

Essa noção do prêmio, ou mesmo do incentivo, não se mostra como reflexo de um valor moral positivo, de forma a satisfazer-se com o aspecto valorativo de abandono da organização criminosa em prol dos valores jurídicos estatais, mas sim de um objetivo político criminal, na medida em que o que interessa para a concessão do benefício é a colaboração que produz efeitos práticos no plano do esclarecimento dos fa$\operatorname{tos}^{23}$. Todavia, a colaboração premiada prevista na Lei n. $12.850 / 13$ não se estabelece focada pura e exclusivamente na perspectiva do prêmio, mas sim enquadrada no âmbito da justiça criminal consensual.

Aliás, o desenvolvimento histórico da delação premiada no Ordenamento Jurídico brasileiro deixa claro que até sua previsão na Lei de Drogas (Lei n. 11.343/06) seu embasamento se dava fundamentalmente na ideia do prêmio, caracterizando este verdadeiro direito subjetivo daquele que delata e alcança resultados previstos na eventual lei que a dispunha. Em geral, o prêmio se concretizava como causa de diminuição de pena.

21 PEREIRA, Frederico Valdez. Delação premiada. Curitiba: Editora Juruá, 2013. p. 29.

22 Ibid. p. 23.

23 Ibid. p. 24. 
Nada obstante, este foco do instituto colaborativo se transmudou a partir da Lei n. 12.529/11, com a previsão do acordo de leniência, o que também se refletiu no estabelecimento de um verdadeiro procedimento de acordo de colaboração premiada na Lei n. 12.850/13.

Observe-se que anteriormente não se falava em um acordo prévio de colaboração, mas simplesmente na estipulação de um prêmio para aquele que colaborasse. Em outras palavras, o foco que antes se dava ao arrependimento processual, e à estipulação de um prêmio para aquele que realizasse a delação premiada, já se apresenta voltado para a expressão de uma verdadeira justiça criminal consensual, em que há um acordo prévio, relativamente negociado, para que se conceda a colaboração premiada.

É com vistas a isto que Gomes e Silva posicionam a colaboração premiada na categoria de justiça colaborativa, sendo esta subespécie da justiça negociada, que por sua vez se faz como subespécie da justiça consensual. Esta última seria o oposto do que se convencionou chamar de modelo de justiça conflitiva (modelo que era fielmente seguido pela justiça criminal brasileira), que não permitia qualquer tipo de negociação entre acusação e defesa ${ }^{24}$.

Dentro da justiça conflitiva, permite-se que um corréu delate o seu comparsa, conforme prevê, por exemplo, a Lei n. 8.072/90 (Lei dos Crimes Hediondos). No entanto, somente falando-se em justiça consensual é que se refere à possibilidade de realização de um acordo com a acusação para a delação.

A quebra do paradigma conflitivo da justiça criminal brasileira se deu na já abordada Lei n. 9.099/95 com a previsão, por exemplo, do instituto da transação penal, que é de característica tipicamente consensual.

Novamente, são abertos espaços de consenso na justiça criminal brasileira com o acordo de leniência da Lei n. 12.529/11, e com o acordo de colaboração premiada da Lei n. $12.850 / 13^{25}$.

24 GOMES, Luiz Flávio; SILVA, Marcelo Rodrigues da. Organizações criminosas e técnicas especiais de investigação. Salvador: JusPODIVM, 2015. p. 217-218.

25 Necessário observar, neste ponto, que ainda que a colaboração premiada e o acordo de leniência se aproximem como expressões contemporâneas da valorização dos espaços de consenso no Ordenamento Jurídico brasileiro, apresentam naturezas jurídicas distintas, já que o acordo de leniência é de 
Constatado isto, é possível a melhor compreensão de que a colaboração premiada ora em estudo se trata necessariamente de um acordo, baseado, portanto, no consenso entre as partes. E tratando-se de consenso, é lógica a necessidade de estar presente a voluntariedade do colaborador, para a realização do acordo. Por outro lado, tratando-se de acordo, também é preciso que as partes se vejam munidas de segurança jurídica naquilo que estabeleceram.

No que se refere ao primeiro fator, há de se distinguir, em um primeiro momento, voluntariedade de espontaneidade. Para que o acusado se torne colaborador, deve realizar o acordo de maneira voluntária. Contudo, seu ato de vontade não precisa ser espontâneo. Em outras palavras, não há a necessidade de que a intenção de praticar o ato nasça exclusivamente da vontade do colaborador, nada impedindo que esta vontade receba influências de seu defensor, do delegado de polícia, ou do Ministério Público. Estas influências, no entanto, devem estar livres de qualquer forma de coação - física, moral ou psicológica - ou mesmo de promessas de vantagens ilegais ${ }^{26}$.

$\mathrm{Na}$ tentativa de assegurar a voluntariedade do colaborador é que o procedimento legal prevê - levando em consideração a frequente vulnerabilidade jurídica, técnica, psíquica, etc., do colaborador - a necessidade de assistência do defensor em todos os atos de negociação, confirmação e execução da colaboração; a necessidade de declaração de aceitação tanto do colaborador quanto do defensor para formalização do termo de acordo; a homologação judicial para análise dos requisitos legais; entre outras disposições.

A voluntariedade é uma das principais justificativas utilizadas para fundamentar a possibilidade de implantação da justiça criminal

natureza administrativa, adstrito aos princípios do processo administrativo, em que se permite que a própria União, por meio da Secretaria de Direito Econômico, firme diretamente o acordo com aquele que comete o ato ilícito. No entanto, coloca-se aqui o acordo de leniência como expressão da justiça criminal consensual em razão de que a própria Lei n. 12.529 de 2011 prevê, em seu artigo 87 que no caso de crimes contra a ordem econômica, a celebração do acordo de leniência não só impede o oferecimento da denúncia, como também permite a extinção da punibilidade caso seja cumprido.

26 GOMES, Luiz Flávio; SILVA, Marcelo Rodrigues da. Organizações criminosas e técnicas especiais de investigação. Salvador: JusPODIVM, 2015. p. 242. 
consensual, e essencialmente para o afastamento de determinadas garantias fundamentais, já que o próprio colaborador estaria, dessa forma, voluntariamente dispondo destas ${ }^{27}$.

Já no tocante à segurança jurídica, é importante ressaltar-se que de nada adianta haver a voluntariedade do colaborador no momento do pacto de colaboração, se, após cumprir seu papel, o estabelecido no acordo não se concretiza na forma como foi negociado. Tampouco se faz pertinente que se conceda o prêmio ao colaborador se de sua colaboração não há resultado qualquer que interesse ao Poder Público. Afinal, cabe frisar que o benefício tem como base não um valor moral positivo, e sim um objetivo político-criminal.

Ao lado do Poder Público, o caput do artigo $4^{\circ}$ da Lei n. 12.850/13 busca essa segurança ao condicionar a concessão do benefício a um ou mais dos resultados taxados nos incisos do mesmo artigo. Pois, no momento do acordo o colaborador não esgota as informações que tem a dispor, mas oferece algumas delas a justificar o alcance de determinados resultados, sendo o relato da colaboração e os possíveis resultados um dos requisitos do termo de acordo (artigo $5^{\circ}$, inciso I da Lei n. 12.850/13).

Já no polo do colaborador, não se denota a mesma segurança, sobretudo nos casos em que não há o chamado "acordo de imunidade" ${ }^{28}$. Na ocasião de não haver o acordo de imunidade, além de previamente homologado o termo de colaboração, o benefício deverá ser proferido em sentença pelo julgador, de modo que neste trâmite, além da ocorrência do resultado, e da efetividade da colaboração como um todo (fatores estes analisados pelo próprio juiz), também avaliará o juiz, para concessão do benefício, critérios subjetivos (como a personalidade do colaborador), assim como critérios objetivos do fato criminoso (como sua natureza e repercussão social), nos moldes do que dispõe o $\S 1^{\circ}$ do artigo $4^{\circ}$ da Lei $n^{\circ} 12.850 / 13^{29}$.

27 FERNANDES, Fernando Andrade. O processo penal como instrumento de política criminal. Coimbra: Almedina, 2001. p. 141.

28 O acordo de imunidade se dá quando estabelecido no termo de colaboração a hipótese de não oferecimento da denúncia, disposta no artigo $4^{\circ}, \S 4^{\circ}$, da Lei $\mathrm{n}^{\mathrm{o}} 12.850 / 13$.

29 "O juiz poderá, a requerimento das partes, conceder o perdão judicial, reduzir em até $2 / 3$ (dois terços) a pena privativa de liberdade ou substituí-la por restritiva de direitos daquele que tenha colaborado efetiva e voluntariamente 
Com efeito, parte expressiva da doutrina entende que a partir do momento em que o colaborador coopera na obtenção de um dos resultados previstos pela Lei cumprindo, assim, efetivamente com aquilo que foi estabelecido no termo de colaboração - o benefício se tornaria um direito público subjetivo ${ }^{30}$. Ademais, existe o entendimento de que a necessidade de homologação judicial do termo de acordo denota expressivo avanço da legislação no que tange à segurança jurídica do colaborador, em especial porque o juiz estaria plenamente vinculado, no momento da sentença, ao acordo devidamente homologado ${ }^{31}$, em vista do que determina o $\$ 11$ do artigo $4^{\circ}$ da Lei ora em análise. E então, no momento da homologação é que seriam analisados, além dos requisitos da legalidade e da voluntariedade, os já citados critérios objetivos e subjetivos relativo ao colaborador e às circunstâncias do acordo.

É imperioso que se reconheça que a necessidade de homologação do termo pode representar um passo em relação à primazia da voluntariedade do colaborador, e da legalidade do procedimento do acordo. Contudo, conforme já dito, o procedimento de homologação traz inúmeras outras questões que afetam drasticamente a segurança jurídica do colaborador, sendo ainda a vinculação do juiz ao acordo homologado ponto eminentemente controverso.

Em primeiro lugar, constata-se tanto em análise ao texto legal, quanto à doutrina e à jurisprudência, que a decisão que homologa o termo de acordo não deve adentrar ao mérito das declarações, tampouco realizar valorações que fujam aos critérios da legalidade, regularidade e voluntariedade do acordo, segundo o que preceitua Mendonça, quando coloca que "visando preservar a imparcialidade do

com a investigação e com o processo criminal, desde que dessa colaboração advenha um ou mais dos seguintes resultados: $[. ..] \S 1^{\circ}$ Em qualquer caso, a concessão do benefício levará em conta a personalidade do colaborador, a natureza, as circunstâncias, a gravidade e a repercussão social do fato criminoso e a eficácia da colaboração."

30 GOMES, Luiz Flávio; SILVA, Marcelo Rodrigues da. Organizações criminosas e técnicas especiais de investigação. Salvador: JusPODIVM, 2015 p. 215.

31 Em apoio à vinculação do juiz ao acordo homologado, as importantes considerações contidas em: FERNANDES, Antonio Scarance. Teoria geral do procedimento e o procedimento no processo penal, p. 258.; SILVA, Eduardo Araújo da. Organizações criminosas, p. 63. 
magistrado, na homologação o magistrado não deve adentrar no mérito do acordo", pois "sua atuação é pautada por assegurar, conforme dito, a legalidade, regularidade e voluntariedade" 32 . Inclusive, a mesma decisão do Supremo Tribunal Federal ${ }^{33}$ que considera o juiz como vinculado ao acordo homologado, coloca que:

\begin{abstract}
A homologação judicial do acordo de colaboração, por consistir em exercício de atividade de delibação, limita-se a aferir a regularidade, a voluntariedade e a legalidade do acordo, não havendo qualquer juízo de valor a respeito das declarações do colaborador.
\end{abstract}

Desse modo, retira-se que a primeira vez em que o magistrado deveria valorizar o mérito, a colaboração realizada, e aquilo que realmente se comprometeu o réu a colaborador no acordo será ao proferir a sentença. Frisa-se que quando se defende a vinculação total do juiz aos termos do acordo de colaboração, utiliza-se do argumento de que durante a homologação já seriam avaliados os critérios legais objetivos e subjetivos do acordo. Entretanto, indaga-se: como pode o magistrado analisar questões tais como as circunstâncias, a gravidade e a repercussão social do fato, ou analisar a regularidade do prêmio oferecido em face da personalidade do colaborador, sem se adentrar ao mérito? E se após a análise do mérito o magistrado passa a discordar de determinada disposição do acordo, pode ele ir contra aquilo que homologou?

A própria Estratégia Nacional de Combate à Corrupção e à Lavagem de Dinheiro (ENCCLA) em seu "Manual de Colaboração Premiada" expõe claramente sua posição de que a homologação não implica qualquer compromisso judicial em acatar aquilo que foi pactuado entre o colaborador e o delegado de polícia, ou o Ministério Pública ${ }^{34}$.

32 MENDONÇA, Andrey Borges de. A colaboração premiada e a nova Lei do Crime Organizado (Lei 12.850/2013). Custos Legis, p. 24.

33 BRASIL. Supremo Tribunal Federal. Habeas Corpus n. 127.483-PR. Paciente: Erton Medeiros Fonseca. Impetrante: José Luiz Oliveira Lima. Coator: Relator da Pet 5244 do Supremo Tribunal Federal. Relator: Ministro Dias Tofoli. Plenário. 27 ago. 2015.

34 ENCCLA. Manual colaboração premiada. ENCCLA 2013. Versão de 24-092013. Aprovado pela Ação n ${ }^{0}$ 9. p. 9. 
Outro fator de extrema importância, levantado por Mendonça ${ }^{35}$, é o fato de que a própria cultura jurídica brasileira não aceitaria tal vinculação do magistrado:

Até mesmo em razão da nossa cultura, em geral não se aceita que o magistrado fique vinculado aos termos do acordo, afirmandose que haveria mera expectativa de direito, não gerando direito subjetivo aos pactuantes, ou qualquer compromisso ou obrigação do julgador.

Para solução do problema, aponta o supracitado autor a necessidade de uma mudança de mentalidade dos operadores do direito ${ }^{36}$ :

É certo que essa questão exigirá certamente uma mudança de mentalidade dos operadores do direito, que muitas vezes é gradual e demorada. Porém, somente com maior respeito ao acordo formulado pelas partes e homologado pelo juiz que a colaboração processual poderá se transformar em eficiente mecanismo de combate à criminalidade organizada.

Cabe ressaltar que, apesar da Lei conferir poder ao juiz de pedir a "adequação" do acordo, não deve ele participar da elaboração deste, devendo menos ainda figurar como parte deste, sob pena de se confundir a figura do magistrado com a do acusador. Considerado isto, torna-se complicada a defesa da plena vinculação do juiz ao acordo, já que não é parte nele. E não estando o magistrado vinculado àquilo que homologou, permanece a insegurança jurídica do colaborador.

Por fim, há de se comentar sobre a tão proferida "eficiência" do acordo. De proêmio, é inegável que a eficiência da colaboração é um critério eminentemente subjetivo a ser analisado, principalmente levando-se em consideração que o que se estabelece no termo de colaboração são expectativas de resultado. Ainda, o réu colaborador não tem controle nenhum sobre a efetividade de sua colaboração, tendo-se

35 MENDONÇA, Andrey Borges de. A colaboração premiada e a nova Lei do Crime Organizado (Lei 12.850/2013). Custos Legis, p. 29-30.

36 Ibid. p. 31. 
em vista que "nenhuma sentença condenatória será proferida com fundamento apenas nas declarações de agente colaborador" ${ }^{37}$. Importa esclarecer que não se posiciona este estudo de forma contrária à necessidade da colaboração em si estar acompanhada de outras provas para que se permita uma sentença condenatória. Apenas coloca-se aqui a realidade de que essa disposição impede fundamentalmente que o colaborador tenha qualquer controle sobre a efetividade de sua colaboração.

Logo, o colaborador conta pouco com a segurança jurídica no acordo de colaboração, já que não há ainda impedimentos concretos de que este, mesmo já tendo sido homologado pelo juiz, passe por novas apreciações, com a avaliação de critérios objetivos e subjetivos, para que seja concedido o benefício. A segurança jurídica das partes no acordo de colaboração é uma questão de extrema complexidade, em vista de que o próprio pacto é realizado sem a completa certeza dos frutos que serão produzidos pela colaboração, e que, em geral, a concretização do acordo não depende exclusivamente da atuação das partes, mas sim da homologação e de novas apreciações pelo juiz para concessão do benefício.

Em suma, o que antes se apresentava pura e exclusivamente como delação premiada, baseada na perspectiva do prêmio e na espontaneidade do réu, inserido na justiça conflitiva; agora se caracteriza como um verdadeiro acordo prévio de colaboração premiada, inserido e um modelo de justiça consensual. E tratando-se de consenso, considerado até mesmo um negócio jurídico, traz-se à tona dois importantes fatores a serem valorizados para que se busque uma utilização da colaboração premiada nos ditames da tutela da dignidade da pessoa humana: a voluntariedade e a segurança jurídica.

\section{DOS PRINCÍPIOS DO CONTRADITÓRIO E DA AMPLA DEFESA NO ACORDO DE COLABORAÇÃO}

Os princípios do contraditório e da ampla defesa representam garantias fundamentais à realização do devido processo legal e da proteção da dignidade da pessoa humana. Ambos, em conjunto, instituem-se

37 Artigo $4^{\circ}, \S 16$, da Lei $n^{\circ} 12.850 / 13$. 
como a pedra fundamental de todo o processo, sobretudo o de natureza penal, considerando-se o paradigma do Estado Democrático de Direito. Afinal,tratando o processo penal do exercício do jus puniendi como ultima ratio, o contraditório e a ampla defesa se fazem primordiais. E como não poderia ser diferente, os ditos princípios se veem consagrados pelo rol de garantias assentado no artigo $5^{\circ}$ da Constituição Federal de 1988, em seu inciso LV: "aos litigantes, em processo judicial ou administrativo, e aos acusados em geral são assegurados o contraditório e ampla defesa, com recursos a ela inerentes".

Ainda que estejam intimamente relacionados, os princípios do contraditório e da ampla defesa representam garantias distintas, conforme se verificará em seguida.

$\mathrm{Na}$ perspectiva do contraditório, envolvem-se, segundo Almeida, três elementos fundamentais: a faculdade de alegar, a faculdade de demonstrar e o direito de ser cientificado dos atos processuais. ${ }^{38}$ Assim, o exercício do contraditório seria uma faculdade, mas a possibilidade de exercê-lo é um direito que envolve a ciência dos atos processuais e de seus inteiros teores.

Nada obstante, o contraditório representa mais do que os aspectos da ciência dos atos e da faculdade de contrariá-los. Na realidade, a doutrina moderna já inclui no contraditório o princípio da par conditio, ou da paridade de armas, o que significa que, mais do que o direito à informação de qualquer fato ou alegação contrário e o direito à reação, também deve-se garantir no processo que a chance de resposta se realize na mesma intensidade e extensão ${ }^{39}$.

Isto porque o contraditório no processo penal, dada sua importância, deve ser pleno e efetivo, não sendo suficiente que se dê a possibilidade formal de se pronunciar contra os atos da parte contrária, caso não sejam proporcionados os meios para que se tenha condições reais de contradizê-los ${ }^{40}$.

38 ALMEIDA, Joaquim Canuto Mendes de. Princípios fundamentais do processo penal. São Paulo: Revista dos Tribunais, 1973. p. 82.

39 OLIVEIRA, Eugênio Pacelli de. Curso de processo penal. 11. ed. Rio de Janeiro: Lumen Juris, 2009. p. 33.

40 FERNANDES, Antônio Scarance. Processo penal constitucional. 5. ed. rev., atual. e ampl. São Paulo: Revista dos Tribunais, 2007. p. 63. 
Já o princípio da ampla defesa retrata a garantia das partes de amplamente argumentarem, podendo, assim, formular quaisquer argumentos possíveis para a construção da decisão, além de poderem atuar na reconstrução de fatos relevantes para a formação da cognição $0^{41}$.

Posto isto, ainda que haja defensores da ideia de que a ampla defesa surge como uma outra medida do contraditório, tratam-se de garantias distintas, realizando cada uma funções de extrema importância para o respeito ao devido processo legal. O contraditório, enquanto entendido como a posição simétrica entre os afetados pela futura decisão judicial, de modo que ambas as partes possam intervir de forma a participar plenamente da construção desta, a ampla defesa retrata, na verdade, a possibilidade da ampla argumentação, podendo se fazer valer de todos os argumentos possíveis, e de todas as possibilidades de produção de provas lícitas.

No caso das garantias do contraditório e da ampla defesa do réu colaborador, importa ilustrar que um dos dispositivos do procedimento legal de colaboração causa alguma incerteza. O $\$ 8^{\circ}$ do artigo $4^{\circ}$ da Lei n. 12.850/13 estabelece que "o juiz poderá recusar a homologação à proposta que não atender aos requisitos legais, ou adequá-la ao caso concreto". Não dispõe a Lei, entretanto, sobre o caminho que se percorrerá no processo após alguma dessas atitudes do juiz. Ocorre que se esta adequação se faz sem consulta às partes, quanto mais ao colaborador, há então uma relevante afronta ao princípio do contraditório e da ampla defesa. Em razão disso, o que se interpreta é que seja dada oportunidade às partes de se manifestarem antes da adequação, com a possibilidade de retratação.

Ademais, o acordo de colaboração, ao distorcer a atuação da defesa técnica, atentaria diretamente ao contraditório, e fundamentalmente à ampla defesa ${ }^{42}$. A obstaculização do direito de defesa por vezes se

41 Observando a ampla defesa a partir de uma reconstrução a partir do Estado Democrático de Direito, entendendo ser uma melhor definição a "ampla argumentação”, cumpre citar a obra PELLEGRINI, Flaviane de Magalhães Barros. et. al. O princípio da ampla defesa: uma reconstrução através do paradigma do Estado Democrático de Direito. Disponível em: <http://www.publicadireito.com.br/conpedi/manaus/arquivos/anais/XIVCongresso/123. pdf>. Acesso em: 07 fev. 2017.

42 VASCONCELLOS, Vinícius Gomes de. Barganha e Justiça Criminal Negocial. São Paulo: IBCCRIM, 2015. p. 185. 
mostra inerente aos mecanismos consensuais, visto que afasta o acusado de sua posição de resistência ao poder punitivo estatal, ocasionando, além disso, a corrupção da relação entre o réu e seu advogado diante das negociações e das supostas vantagens de eventual acordo. Isto porque as delações geram inevitáveis "tentações" ao patrono, colocando este em sentido oposto ao interesse do acusado ${ }^{43}$.

Observa-se que com a intenção de garantir a voluntariedade do réu colaborador, a Lei n. 12.850/13 impõe a presença do defensor nos acordos de colaboração, assinando, inclusive, junto os respectivos termos. Todavia, repara-se que tal presença do defensor demonstra um paradoxo ao menos preocupante, já que ele poderá anuir com o reconhecimento da culpabilidade de seu cliente, em nome de um prêmio, ou da insegurança com determinados resultados do processo, enquanto deveria reagir contra o poder punitivo ${ }^{44}$.

Assim, como se pode observar, a tensão entre a colaboração premiada e as garantias do contraditório e da ampla defesa no plano do colaborador se dá, primordialmente, não em determinadas falhas do procedimento, com desenhadas restrições à participação efetiva e à ampla argumentação, mas sim nos efeitos que a barganha pode tomar em relação à defesa técnica como um todo.

Não se ignora aqui a existência de relevantes questões acerca das garantias do contraditório e da ampla defesa no plano do delatado, matéria que, no entanto, foge ao objeto deste artigo, que se resume às garantias do colaborador.

Em suma, o próprio mecanismo consensual, por sua natureza, pode abrir espaço a determinadas fragilizações que transpassam a tutela da dignidade humana, pelo comprometimento do contraditório e da ampla defesa e, consequentemente, do devido processo legal, através da distorção da atuação defensiva no processo penal.

Ibid. p. 184.

44 MANDARINO, Renan Posella. Limites probatórios da delação premiada frente à verdade no processo penal. In: Aspectos penais controversos da colaboração premiada: monografias vencedoras 2016 - IASP|CIEE - Esther Figueiredo Ferras. São Paulo: Editora IASP, 2016. p. 257. 


\section{DA PRESUNÇÃO DE INOCÊNCIA E DA NÃO-AUTOINCRIMINAÇÃO NO ACORDO DE COLABORAÇÃO}

A Constituição Federal de 1988 estabeleceu como requisito objetivo para o momento da "prova efetiva" o trânsito em julgado da sentença penal condenatória ${ }^{45}$, conforme se coloca em seu artigo $5^{\circ}$, inciso LVII, o qual dispõe: "ninguém será considerado culpado até o trânsito em julgado da sentença penal condenatória”.

A presunção de inocência tem origem no pensamente iluminista francês, sendo consagrada e mantida desde a sua previsão na Declaração dos Direitos do Homem e do Cidadão de 1789, de forma a tomar o status quo científico, social, político e filosófico desde então ${ }^{46}$. Segundo Zanoide de Moraes, "por ela, todos são inocentes e gozam desse estado político diante do poder estatal até que, por meio de um sistema probatório racional, consiga-se demonstrar que a conduta externa do cidadão é um crime" ${ }^{47}$.

No Ordenamento Jurídico brasileiro, conforme se pode observar com sua previsão no rol de garantias fundamentais, a presunção de inocência é um princípio de importância basilar, sendo um dos notáveis reflexos do valor fundamental da tutela da dignidade da pessoa humana. Inicialmente, constata-se que é da lógica do próprio acordo de colaboração premiada que o colaborador se responsabilize - em outras palavras, que se declare culpado - ao menos em parte pelo delito em questão. Isto porque o instituto cuida justamente de oferecer prêmio àquele informante envolvido no âmbito das atividades delitivas da organização criminosa ${ }^{48}$.

45 Com efeito, o Supremo Tribunal Federal, em decisão recente, mudou seu posicionamento decidindo pela constitucionalidade da execução provisória da pena a partir da decisão de segundo grau, e antes do próprio trânsito em julgado. (Disponível em: <http://www.stf.jus.br/portal/cms/verNoticiaDetalhe .asp?idConteudo=326754>. Acesso em: 14 fev. 2017). Contudo, o posicionamento vem sendo notadamente contestado pela doutrina, sendo controverso mesmo entre os próprios Ministros da Suprema Corte, em razão da clareza com que tanto da Constituição Federal, como do próprio Código de Processo Penal, em estabelecer o marco do trânsito em julgado da sentença condenatória para a prova efetiva.

46 MORAES, Maurício Zanoide de. Presunção de inocência no processo penal brasileiro. Rio de Janeiro: Lumen Juris, 2010. p. 90.

47 Ibid. p. 91.

48 Diante do comentado no tópico anterior sobre o desvirtuamento da defesa técnica, ainda que plenamente condenável, não há como ignorar, neste pon- 
Dessa forma, muito embora o ônus probatório no processo penal seja exclusivo da acusação, em nome da presunção de inocência ${ }^{49}$, nada impede que o próprio acusado ateste sua responsabilidade pelo crime. Até esta parte do raciocínio, não há conflito da colaboração premiada com o princípio da presunção de inocência, já que não existem impedimentos para que ele confesse. É evidente, por outro lado, que tal atestado deve ocorrer de forma voluntária ${ }^{50}$, sem qualquer tipo de coação por parte da acusação ou do julgador.

Do princípio da presunção de inocência derivam outros princípios como o in dúbio pro reo, em que, permanecendo dúvida sobre a materialidade do delito e/ou a autoria do réu, deve este ser absolvido; e principalmente o princípio do nemo tenetur detegere, também denominado princípio da não-autoincriminação, em que se baseiam a garantia de silêncio e de não ser obrigado a provar contra si mesmo.

Em razão do direito ao silencio, o réu não é obrigado a se pronunciar em nenhum de seus interrogatórios, garantia da qual o acusado deve, inclusive, ser informado pela eventual autoridade, segundo dispõe o inciso LXIII do artigo $5^{\circ}$, da Constituição Federal de 1988. Cabe destacar que tanto em vista do princípio da presunção de inocência,

to, a figura do colaborador que queira/prefira ser considerado envolvido, e que coopera para a investigação da conduta criminosa. Em outras palavras, senão realmente culpado, há aquele que se coloca como colaborador por pelo menos entender ser mais favorável estrategicamente realizar o acordo de colaboração premiada ao ingressar normalmente no processo como réu. Neste caso, há plena tensão em relação ao princípio da culpabilidade, além de estabelecer-se uma situação drasticamente contrária aos objetivos de um Sistema Jurídico-Penal pautado pelo direito penal mínimo, característico de um Estado Democrático de Direito. Tais questões, entretanto, não terão maior aprofundamento neste trabalho, dado que fogem de seus objetivos.

Cabe considerar que no processo penal, a prova da alegação cabe a quem a fizer, na forma do caput do artigo 156 do Código de Processo Penal. No entanto, a prova efetiva do ilícito penal e da responsabilidade penal cabe à acusação, não tendo o acusado que comprovar sua inocência, a não ser que o contexto processual o requeira para assegurar o pleito absolutório. Ou seja, se nada alegar o réu, e a prova da acusação for insuficiente, não são permitidas inversões do ônus da prova, prevalecendo, na dúvida, a inocência (in dúbio pro reo).

Fala-se aqui em voluntariedade, e não espontaneidade. Portanto, pode haver influência do delegado ou do Ministério Público, por meio do oferecimento de prêmios, por exemplo. O que não se pode admitir é algum tipo de coação física ou moral para que alguém colabore. 
quanto da ampla defesa, a escolha do réu pelo silêncio não pode ser utilizada contra si para eventual condenação ${ }^{51}$. Ademais, como o acusado não pode ser compelido a produzir prova contra si, a ele não é imposto o dever de dizer a verdade.

Uma das imposições colocadas pela colaboração premiada é que o colaborador renuncie, em todos os depoimentos que prestar, ao direito ao silêncio, e que a partir de então estará sujeito ao compromisso legal de dizer a verdade ( $\$ 14$, artigo $7^{\circ}$ ). Esse, sem dúvida, é o mais expresso afastamento de garantias fundamentais do procedimento de colaboração, sendo, então, uma das questões de maior polêmica.

Por certo, também inútil seria o acordo de colaboração premiada, como instrumento de política criminal a garantir uma maior eficiência/funcionalidade ao processo penal, se o colaborador pudesse permanecer inerte, ou não houvesse de se comprometer com a verdade. Aliás, de nada valeria o depoimento de um colaborador se não fosse vedado a ele faltar com a verdade.

O fator que legitima a possibilidade de afastamento da garantia do silêncio e da não-autoincriminação é justamente a voluntariedade do acusado em se tornar colaborador. Em razão disso é que o mesmo $\$ 14$ do artigo $7^{\circ}$ da Lei n. 12.850/13 determina que o depoimento e a renúncia devem ser realizados na presença do defensor (o que, por outro lado, também causa inquietações, como observado no tópico anterior). A mesma preocupação se extrai do artigo $6^{\circ}$, inciso IV, o qual exige que também conste a assinatura do defensor no termo de colaboração.

Nada obstante, outro instituto do processo penal vem causando preocupações relativas à voluntariedade do colaborador: a prisão preventiva. Trata-se de uma forma de prisão cautelar, calcada nos artigos 311 a 316 do Código de Processo Penal brasileiro. Poderá ser decretada quando houver prova de existência de crime e indício de autoria, na forma do artigo 312 do CPP, quando restar devidamente configurados nos autos que o imputado prejudicará a instrução do processo, ou que frustrará aplicação da lei penal, ou até mesmo que ameaçará a garantia da ordem pública ou da ordem econômica.

51 Artigo 186, parágrafo único, Código de Processo Penal brasileiro. 
Com efeito, a reforma realizada no regime das prisões cautelares pela Lei $\mathrm{n}^{\circ} 12.403 / 11$ buscou se adaptar ao sistema internacional de proteção aos direitos humanos, de modo a estabelecer, ao menos no plano normativo, a prisão preventiva como ultima ratio do sistema ${ }^{52}$. No entanto, a manutenção da garantia da ordem pública como um dos fundamentos para a decretação da prisão preventiva é alvo de críticas de grande parte da doutrina.

Afinal, cabe ressaltar que a prisão cautelar é regida pelo princípio da legalidade estrita, de forma que "a prisão de qualquer pessoa necessita cumprir requisitos formais estritos” ${ }^{3}$, o que não condiz com o disposto no artigo 312 do CPP. O termo ordem pública se mostra vago, além de depender da valoração axiológica, o que abre uma imensa margem de interpretação ao julgador.

Consequentemente, a amplitude da aplicação da prisão preventiva pode decorrer em prisões realizadas somente com o intuito de se conseguir uma delação, o que sem sombra de dúvidas, afronta a voluntariedade do acusado e prejudica drasticamente a tutela da dignidade humana.

Outrossim, condiciona-se a prisão à presença de indícios de autoria e materialidade, o que pode ter objeto uma colaboração premiada, já que a Lei somente veda a delação como prova exclusiva para condenação. Assim, o ciclo que se pode formar é o seguinte: $\left(1^{\circ}\right)$ colhe-se uma colaboração, a qual acaba sendo considerada integralmente como indício de autoria e materialidade do delito para se decretar a prisão preventiva do delatado, apoiado em um dos convenientes critérios; $\left(2^{\circ}\right)$ agora preso, o delatado é "convencido" a realizar nova colaboração. Essa preocupação também é expressa por Pereira ${ }^{54}$ :

Nesse aspecto em alguma medida regressivo do sistema processual, o instituto da prisão preventiva pode tornar-se, acaso mal utilizado, o instrumento principal de provocação da atitude colabora-

52 SILVEIRA, Felipe Lazzari da. A banalização da prisão preventiva para a garantia da ordem pública. Revista da Faculdade de Direito da UFMG, Belo Horizonte, n. 67, p. 213-244, jul./dez. 2015. p. 214.

53 NUCCI, Guilherme de Souza. Leis penais e processuais penais comentadas. 8. ed. v. 2. Rio de Janeiro: Forense, 2014. p. 109.

54 PEREIRA, Frederico Valdez. Delação premiada. Curitiba: Juruá, 2013. p. 67. 
tiva, levando o imputado quase à condição de meio de prova, com possíveis reflexos também em perversa contaminação policialesca do processo, no caso de o juiz assumir precipuamente as funções de combater a criminalidade organizada e distorcer a presunção de não culpabilidade em relação ao corréu não colaborante.

Além disso, o Superior Tribunal de Justiça brasileiro chegou a reconhecer o descumprimento do acordo de colaboração como motivo para restabelecer-se a prisão preventiva ${ }^{55}$, o que, se não afronta o princípio da legalidade restrita da prisão cautelar, ao menos representa considerável ameaça e insegurança ao colaborador. Acertadamente, a decisão foi reformada pelo Supremo Tribunal Federal, em sede de liminar proferida pelo saudoso Ministro Teori Zavaski. Na decisão, o Ministro defende não haver relação legal entre a delação premiada e a prisão preventiva ${ }^{56}$.

Por fim, ainda relativo à garantia de não-autoincriminação, observa-se que a já comentada insuficiente segurança jurídica oferecida ao colaborador o impõe o ônus probatório do delito, já que se sua colaboração não for efetiva, não recebe o benefício, o que atenta não só contra esse princípio, como também à presunção de inocência como um todo.

Resumindo, a presunção de inocência e de não-autoincriminação são as garantias fundamentalmente afetadas pela colaboração premiada. De fato, para que se tenha o processo penal como instrumento de política criminal se defende a dispensa de determinadas garantias em nome de uma maior eficiência do processo, desde que não se transgrida a barreira da tutela da dignidade humana. O procedimento legal do acordo de colaboração premiada, no que toca à presunção de inocência e a não-autoincriminação, fere a tutela da dignidade da pessoa humana, tanto por aspectos interiores ao procedimento, como por medidas do próprio processo penal geral, por exemplo, a prisão preventiva.

55 BRASIL. Superior Tribunal de Justiça. Recurso em Habeas Corpus $n$. 76.026-RS. Recorrente: Fernando Antonio Guimaraes Hourneaux De Moura. Recorrido: Ministério Público Federal. Relator: Ministro Felix Fischer. 5 ${ }^{\mathrm{a}}$ Turma. 11 out. 2016.

56 RICHTER, André. Ministro do STF diz que quebra de acordo de delação não justifica prisão. Disponível em: <http://agenciabrasil.ebc.com.br/politica/ noticia/2016-11/ministro-do-stf-diz-que-quebra-de-acordo-de-delacaonao-justifica-prisao>. Acesso em: 14 fev. 2017. 


\section{Considerações FinAIS}

Os novos aspectos trazidos ao Direito Penal pela nova configuração da sociedade trouxeram questões também da natureza processual penal, entre elas a dificuldade de se investigar determinadas condutas como aquelas produzidas por organizações criminosas. É neste contexto que surge o acordo de colaboração premiada. E, justamente por surgir como uma resposta do Direito Penal a essa dificuldade que se entende ser a colaboração premiada um instrumento de política criminal.

Na relação entre as ciências jurídico-criminais não há mais espaço para a segregação completa entre a dogmática jurídico-criminal e a política criminal, de forma que não mais cabe a segregação entre o pensamento do sistema e o pensamento do problema. Afinal, se a dogmática representasse exclusivamente a proteção ao acusado, e à política criminal restasse somente a preocupação com soluções para a criminalidade, ter-se-ia um Direito Penal plenamente alheio às questões reais da sociedade.

Seguindo este raciocínio, conclui-se deve haver complementariedade funcional entre o Direito Penal material e o processo penal, pois não há como se buscar a eficiência dos objetivos de Direito Penal substancial sem um procedimento que o permite. Em razão disso é que se defende o processo penal como instrumento de política criminal.

Para um processo penal como instrumento de política criminal, o que se pensa é no equilíbrio entre os vetores da eficiência/funcionalidade do processo penal e do garantismo por este exercido. Assim, o que se propõe é o afastamento das garantias que não sejam necessárias à intransponível barreira da tutela da dignidade da pessoa humana. No entanto, isso se daria através da diversificação processual, levados por um verdadeiro prognóstico de natureza político criminal, e pela integração teleológica entre o processo penal, e os valores político-criminais do Sistema Jurídico-Criminal.

No caso brasileiro, a expressão do processo penal como instrumento de política criminal se deu, de início, no âmbito da criminalidade leve, com o implemento e mecanismos de natureza consensual, como a suspensão condicional do processo e a transação penal, trazidos pela Lei n. 9.099/95. 
Agora o mesmo movimento ocorre, entretanto em direção à criminalidade grave, com a previsão do acordo de colaboração premiada na Lei n. 12.850/13.

Com a Lei n. 12.850/13, a delação premiada surge na forma de um acordo de colaboração premiada, o que, conquanto já fosse realizado na prática, carecia de um procedimento legal que envolvesse toda a sua complexidade.

O procedimento previsto pela Lei das Organizações Criminosas tratou de determinados problemas clamados pela doutrina. Todavia, o que ali se prevê está longe de cumprir com toda a complexidade de um acordo de colaboração premiada, tratando superficialmente de questões sérias como a segurança jurídica e a voluntariedade do colaborador. Ademais, também se fazem existentes problemas relativos ao contraditório e à ampla defesa e, consequentemente ao devido processo penal.

Com efeito, é de todo lúcida a ideia do processo penal como instrumento de política criminal para buscar-se uma maior e necessária coerência e funcionalidade dentro do Sistema Jurídico-Criminal.

$\mathrm{E}$, neste sentido, também se mostra interessante a ideia da colaboração premiada como instrumento de política criminal, a fim de trazer o processo penal, e o Sistema Jurídico-Criminal como um todo, para a realidade da configuração da sociedade. Contudo, essa expressão da justiça criminal negociada não deve ocorrer de modo a realizar-se uma mera importação jurídica, seja das experiências europeias, seja das origens anglo-saxãs. A previsão da colaboração premiada deve ser coerente com Ordenamento Jurídico brasileiro, como também deve estar adequada à tradição jurídica do Brasil.

Visto que a Constituição Federal brasileira de 1988 estabelece o modelo de Estado Democrático de Direito, as opções político-criminais ao menos devem ser coerentes com este modelo de estado, e com os princípios dele advindos. Neste caso, para manter a coerência deve se respeitar ao menos a barreira intransponível da tutela da dignidade da pessoa humana, valor maior do modelo de estado constitucionalmente estabelecido no Brasil.

E, conforme demonstrado, o procedimento do acordo de colaboração premiada da Lei n. 12.850/13 ainda se mostra carente no que tange às complexidades do Instituto, e à sua tensa relação com os limites processuais. 


\section{REFERÊNCIAS BIBLIOGRÁFICAS}

ALMEIDA, Joaquim Canuto Mendes de. Princípios fundamentais do processo penal. São Paulo: Revista dos Tribunais, 1973.

BAUMAN, Zigmunt. Globalização: as consequências humanas. Tradução: Marcos Penchel. Rio de Janeiro: Editora Jorge Zahar, 1999.

BECK, Ulrich. Sociedade de risco. Tradução: Sebastião Nascimento. 2. ed. São Paulo: Editora 34, 2011.

CARVAlHO, L. G. Grandinetti Castanho de. Processo penal e constituição: princípios constitucionais do processo penal. 5. ed. rev. ampl. Rio de Janeiro: Editora Lumen Juris, 2009.

DIAS, Jorge de Figueiredo. Acordos sobre a sentença em processo penal: o fim do Estado de Direito ou um novo "princípio"? Porto: Conselho Distrital do Porto da Ordem dos Advogados, 2011.

DIAS, Jorge Figueiredo. Os novos rumos da política criminal e o direito penal português do futuro. Coimbra: ROA, 1983.

FARIA, José Eduardo. Direito e globalização econômica: implicações e perspectivas. São Paulo: Malheiros, 1996.

FERRAJOLI, Luigi. Direito e razão: teoria do garantismo penal. 3 ed. rev. São Paulo: Revista dos Tribunais, 2010.

FERNANDES, Antônio Scarance. Processo penal constitucional. 5. ed. rev., atual. e ampl. São Paulo: Revista dos Tribunais, 2007.

FERNANDES, Antonio Scarance. Teoria geral do procedimento e o procedimento no processo penal. São Paulo: Revista dos Tribunais, 2005.

FERNANDES, Fernando Andrade. O processo penal como instrumento de política criminal. Coimbra: Almedina, 2001.

FERNANDES, Fernando Andrade. Sobre uma opção jurídico-política e jurídicometodológica de compreensão das ciências jurídico-criminais. In: COSTA ANDRADE, Manuel da et al. (Org.). Liber Discipulorum para Jorge de Figueiredo Dias. Coimbra: Editora Coimbra, 2003.

GOMES, Luiz Flávio; SILVA, Marcelo Rodrigues da. Organizações criminosas e técnicas especiais de investigação: questões controvertidas, aspectos teóricos e prático e análise da Lei 12.850/2013. Salvador: JusPODIVM, 2015.

HABIB, Gabriel. Leis penais especiais. 5. ed. tomo II. Bahia: JusPODIVM, 2014.

HASSEMER, Winfried. La ciência jurídico penal en la república federal alemana. Trad. Hernán Hormanazabal Malarée. Anuario de Derecho Penal y Ciencias Penales. t. XLVI, f. I. Madrid: ene./abr. 1993. p. 35-80. 
MANDARINO, Renan Posella. Limites probatórios da delação premiada frente à verdade no processo penal. In: Aspectos penais controversos da colaboração premiada: monografias vencedoras 2016 - IASP|CIEE - Esther Figueiredo Ferras. 1. ed. São Paulo: Editora IASP, 2016.

MENDONÇA, Andrey Borges de. A colaboração premiada e a nova Lei do Crime Organizado (Lei 12.850/2013). Custos Legis: Revista eletrônica do Ministério Público Federal, v. 4, p. 01-38, 2013.

MORAES, Maurício Zanoide de. Presunção de inocência no processo penal brasileiro: análise de sua estrutura normativa para a elaboração legislativa e para a decisão judicial. Rio de Janeiro: Lumen Juris, 2010.

NUCCI, Guilherme de Souza. Leis penais e processuais penais comentadas. 8. ed. v. 2. Rio de Janeiro: Forense, 2014.

NUCCI, Guilherme de Souza. Manual de processo penal e execução penal. 10. ed. rev. atual. e ampl. São Paulo: Editora Revista dos Tribunais, 2013.

OLIVEIRA, Eugênio Pacelli de. Curso de processo penal. 11. ed. Rio de Janeiro: Lumen Juris, 2009.

PELLEGRINI, Flaviane de Magalhães Barros. et. al. O princípio da ampla defesa: uma reconstrução através do paradigma do Estado Democrático de Direito. Disponível em http://www.publicadireito.com.br/conpedi/manaus/arquivos/ anais/XIVCongresso/123.pdf. Acesso em: 07 fev 2017.

PEREIRA, Frederico Valdez. Delação premiada: legitimidade e procedimento. Curitiba: Juruá, 2013.

RODRIGUES, Anabela Maria M. A determinação da medida da pena privativa de liberdade. Coimbra: Coimbra Editora, 1995.

ROXIN, Claus. Estudos de Direito Penal. Tradução: Luís Greco. Rio de Janeiro: Renovar, 2006.

ROXIN, Claus. Política criminal e sistema jurídico penal. Tradução: Luis Greco. Rio de Janeiro: Renovar, 2000.

SILVA, Eduardo Araújo. Organizações criminosas: aspectos penais e processuais da Lei n ${ }^{\circ}$ 12850/13. São Paulo: Atlas, 2014.

SILVEIRA, Felipe Lazzari da. A banalização da prisão preventiva para a garantia da ordem pública. Revista da Faculdade de Direito da UFMG, Belo Horizonte, n. 67, p. 213-244, jul./dez. 2015. https://doi.org/10.12818/p.0304$2340.2015 \mathrm{v} 67 \mathrm{p} 213$

VASCONCELLOS, Vinícius Gomes de. Barganha e Justiça Criminal Negocial: análise das tendências de expansão dos espaços de consenso no processo penal brasileiro. São Paulo: IBCCRIM, 2015. 
Dados do processo editorial

(http://www.ibraspp.com.br/revista/index.php/RBDPP/about/editorialPolicies)

- Recebido em: 08/01/2017

Equipe editorial envolvida

- Controle preliminar e verificação de plágio: 08/01/2017

- Avaliação 1: 10/01/2017

- Avaliação 2: 14/01/2017

- Editor-chefe: 1 (VGV)

- Editora-associada: 1 (SRM)

- Revisores: 3

- Avaliação 3: 22/01/2017

- Decisão editorial preliminar: 23/01/2017

- Retorno rodada de correções 1:08/02/2017

- Decisão editorial 2: 09/02/2017

- Retorno rodada de correções 2: 15/02/2017

- Decisão editorial final: 17/02/2017

\section{COMO CITAR ESTE ARTIGO:}

AIRES, Murilo T.; FERNANDES, Fernando A. A colaboração premiada como instrumento de política criminal: a tensão em relação às garantias fundamentais do réu colaborador. Revista Brasileira de Direito Processual Penal, Porto Alegre, vol. 3, n. 1, p. 253-284, jan./abr. 2017. https://doi.org/10.22197/rbdpp.v3i1.46

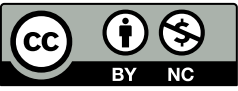

Esta obra está licenciada com uma Licença Creative Commons Atribuição-NãoComercial 4.0 Internacional. 